\title{
Paenibacillus hunanensis sp. nov., isolated from rice seeds
}

\author{
Yang Liu, ${ }^{1} \dagger$ Lin Liu, ${ }^{1} \dagger$ Fubin Qiu, ${ }^{2}$ Peter Schumann, ${ }^{3}$ Yu Shi, ${ }^{4}$ \\ Yuanyuan Zou, ${ }^{1}$ Xiaoxia Zhang ${ }^{4}$ and Wei Song ${ }^{1}$ \\ ${ }^{1}$ College of Life Sciences, Capital Normal University, Beijing 100048, PR China \\ ${ }^{2}$ College of Public Health, Shanxi Medical University, Taiyuan 030001, PR China \\ ${ }^{3} \mathrm{DSMZ}$ - Deutsche Sammlung von Mikroorganismen und Zellkulturen GmbH, Inhoffenstraße 7B, \\ 38124 Braunschweig, Germany \\ ${ }^{4}$ Agricultural Cultural Collection of China, Institute of Agricultural Resources and Regional Planning, \\ Chinese Academy of Agricultural Sciences, Beijing 100081, PR China
}

Correspondence

Wei Song

songwei@mail.cnu.edu.cn

Xiaoxia Zhang

xxzhang@caas.ac.cn

\begin{abstract}
Four Gram-stain-positive, aerobic or facultatively anaerobic, motile, endospore-forming, rodshaped bacteria, designated strains FeL05 ${ }^{\top}$, FeL11, Fek19 and Fek21, were isolated from seeds of hybrid rice (Oryza sativa L. Jinyou 611), and their taxonomic positions were determined using a polyphasic approach. Phylogenetic analysis based on 16S rRNA gene sequences showed that the four strains were members of the genus Paenibacillus. They showed $95.4 \%$ sequence similarity or less with strains of other Paenibacillus species. The $\mathrm{G}+\mathrm{C}$ content of strain FeL05 was found to be $53.3 \mathrm{~mol} \%$. Its predominant respiratory quinone was MK-7. The predominant cellular fatty acids were anteiso- $\mathrm{C}_{15: 0}(61.7 \%), \mathrm{C}_{16: 0}(10.9 \%)$, iso- $\mathrm{C}_{16: 0}(7.0 \%)$, anteiso$\mathrm{C}_{17: 0}(6.7 \%)$ and iso- $\mathrm{C}_{15: 0}(5.2 \%)$. On the basis of its phenotypic properties and phylogenetic distinctiveness, strain FeL05 ${ }^{\top}$ represents a novel species of the genus Paenibacillus, for which the name Paenibacillus hunanensis sp. nov. is proposed. The type strain is strain FeL05 ${ }^{\top}$ $\left(=\right.$ ACCC $10718^{\top}=$ CGMCC $1.8907^{\top}=$ DSM $\left.22170^{\top}\right)$.
\end{abstract}

Paenibacillus species are aerobic or facultatively anaerobic, endospore-forming, rod-shaped bacteria and are widely distributed in nature (Slepecky \& Hemphill, 1992; Claus \& Berkeley, 1986). These micro-organisms are very important from industrial and economic points of view (Slepecky \& Hemphill, 1992; Priest, 1977; Chung et al., 2000; WeonTaek et al., 1999). Moreover, many species of the genus, including the type species, Paenibacillus polymyxa, have been reported as plant growth-promoting rhizobacteria (Lebuhn et al., 1997; Timmusk \& Wagner, 1999; Timmusk et al., 1999; Helbig, 2001; Beatty \& Jensen, 2002; Maes \& Baeyen, 2003; von der Weid et al., 2003). In this paper, we report the taxonomic characterization of four novel bacterial strains, FeL05 ${ }^{\mathrm{T}}, \mathrm{FeL11}, \mathrm{Fek} 19$ and Fek21, isolated from seeds of hybrid rice (Oryza sativa L. Jinyou 611) sampled from the China National Hybrid Rice R\&D

†These authors contributed equally to this work.

The GenBank/EMBL/DDBJ accession numbers for the $16 \mathrm{~S}$ rRNA gene sequences of strains FeL05 ${ }^{\top}$, FeL11, Fek19 and Fek21 are EU741036, EU741039, EU741029 and EU741031, respectively.

Details of acid production and fatty acid profiles of the novel strains and related type strains and an electron micrograph of cells of strain FeLO5 ${ }^{\top}$ are available as supplementary material with the online version of this paper.
Center, which is situated in Hunan Province. 16S rRNA gene sequencing and biochemical tests showed that these bacterial isolates constituted a novel species of the genus Paenibacillus.

Strain FeL05 ${ }^{\mathrm{T}}$ and FeL11 were originally isolated on plates of Luria-Bertani (LB) agar $\left(1^{-1}: 10 \mathrm{~g}\right.$ casein peptone, $5 \mathrm{~g}$ yeast extract, $10 \mathrm{~g} \mathrm{NaCl} ; \mathrm{pH} 7.0)$, while Fek19 and Fek21 were originally isolated on plates of King's B (KB) agar $\left(1^{-1}: 20 \mathrm{~g}\right.$ proteose peptone, $1.5 \mathrm{~g} \mathrm{~K}_{2} \mathrm{HPO}_{4}, 1.5 \mathrm{~g}$ $\mathrm{MgSO}_{4} \cdot 7 \mathrm{H}_{2} \mathrm{O}, 15 \mathrm{ml}$ glycerol; $\mathrm{pH}$ 7.2), both of which had been seeded with a suspension of hybrid rice seeds and incubated at $28{ }^{\circ} \mathrm{C}$ for 3 days. The seed suspension was prepared according to the following procedure, as described by Qiu et al. (2007). Seeds were washed with tap water, surface-sterilized with $75 \%$ ethanol for $3 \mathrm{~min}$ and $2.6 \%$ sodium hypochlorite solution for $5 \mathrm{~min}$ and then rinsed with sterile double-distilled water $\left(\mathrm{ddH}_{2} \mathrm{O}\right)$. The surface-sterilized seeds were pulverized in a ceramic mortar and diluted with sterile $\mathrm{ddH}_{2} \mathrm{O}$ using the standard dilution-plating technique. The new isolates were maintained on LB agar slants at $4{ }^{\circ} \mathrm{C}$ and as glycerol suspensions $(20 \%, v / v)$ at $-20{ }^{\circ} \mathrm{C}$. Biomass for chemotaxonomic and molecular systematic studies was prepared by growing the strains in shake flasks of LB broth at $28{ }^{\circ} \mathrm{C}$ for $1-2$ days. Cells were harvested by centrifugation and washed with 
$\mathrm{ddH}_{2} \mathrm{O}$ and then freeze-dried before use in physiological and biochemical studies.

Colonial properties of the isolates were observed on LB agar. Cell morphology was examined by light microscopy and transmission electron microscopy (TEM). The presence of flagella was investigated by TEM. Gram staining was carried out using a standard procedure (Hucker \& Conn, 1923). Utilization of a variety of substrates as sole carbon sources was tested using the GP2 MicroPlate Gram Positive Identification test panel (Biolog). In addition, acid-production tests were performed with the API $50 \mathrm{CH}$ identification system according to the instructions of the manufacturer (bioMérieux).

Purified peptidoglycan preparations were obtained after disruption of cells by shaking with glass beads and subsequent trypsin digestion according to the method of Schleifer (1985). Amino acids and peptides in cell-wall hydrolysates were analysed by two-dimensional ascending TLC on cellulose plates by using previously described solvent systems (Schleifer, 1985). Molar ratios of amino acids were determined by GC and GC-MS of N-heptafluorobutyryl amino acid isobutyl esters (MacKenzie, 1987). Cellular menaquinones were extracted and purified as described by Collins (1985) and were analysed by HPLC (Wu et al., 1989). Polar lipids extracted by the method of Minnikin et al. (1979) were identified by two-dimensional TLC and spraying with specific reagents as described by Collins \& Jones (1980). Non-hydroxylated fatty acids were extracted, purified, methylated, identified and quantified by gas chromatography with the standard Microbial Identification System (MIDI) (Sasser, 1990; Kämpfer \& Kroppenstedt, 1996).

A loop of biomass was scraped off the agar plate,

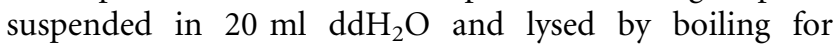
$10 \mathrm{~min}$ and freezing for $5 \mathrm{~min}$. Following centrifugation, the supernatant was used as the template for PCR. The $16 \mathrm{~S}$ rRNA gene was amplified using the universal primers $27 \mathrm{~F}$ (5'-AGAGTTTGATCCTGGCTCAG-3') and 1492R (5'GGTTACCTTGTTACGACTT-3') (Lane, 1991). Amplified products were purified and cloned into vector Top10 (Tiangen) for sequence determination. Automated sequencing was performed by using an ABI Big Dye Primer cyclesequencing ready reaction kit and Applied Biosystems 3730 DNA sequencer. The sequencing primers were SP6 (5'-ATTTAGGTGACACTATAGAATAC-3') and T7 (5'-TAATACGACTCACTATAGGG-3'). The 16S rRNA gene sequences of the four novel bacterial strains and those of other members of the genus Paenibacillus retrieved from GenBank were aligned using the program CLUSTAL_X version 1.8 (Thompson et al., 1997). Three tree-making algorithms, the neighbour-joining (Saitou \& Nei, 1987), maximum-parsimony (Eck \& Dayhoff, 1966; Fitch, 1971) and minimum-evolution (Rzhetsky \& Nei, 1992) methods from MEGA4 (Tamura et al., 2007), were used to infer phylogenetic evolutionary trees. Percentages of replicate trees in which the associated taxa clustered together in the bootstrap test (1000 replicates) are shown next to branches (Felsenstein, 1985).

Preparation of genomic DNA was carried out according to the method of Marmur (1961). The G+C content of the DNA was determined using the thermal denaturation method (Marmur \& Doty, 1962) with DNA from Escherichia coli $\mathrm{K}-12$ as a control.

Comparisons with the GenBank database by BLAST search revealed that the sequences of the new isolates did not match those of any known bacterium. The bacterium with the greatest pairwise identity to strain $\mathrm{FeL} 05^{\mathrm{T}}$ was Paenibacillus kribbensis $\mathrm{AM}_{4} 9^{\mathrm{T}}(95.35 \%)$. Comparative $16 \mathrm{~S}$ rRNA gene sequence similarity analysis revealed that the similarities among strains FeL05 ${ }^{\mathrm{T}}$, FeL11, Fek19 and Fek21 were more than $99 \%$. The phylogenetic tree constructed using the neighbour-joining method (Fig. 1) suggested that strains FeL05 ${ }^{\mathrm{T}}$, FeL11, Fek19 and Fek21 are members of the genus Paenibacillus but represent a distinct species. Phylogenetic trees inferred by the maximumparsimony and minimum-evolution methods showed relationships similar to those given by the neighbourjoining method (not shown).

Morphological, cultural, physiological and biochemical characteristics of strains FeL05 ${ }^{\mathrm{T}}$, FeL11, Fek19 and Fek21 are given in the species description and in Table 1 and Supplementary Table S1 (available in IJSEM Online), which show distinctive features of the four strains as well as those of closely related species belonging to the genus Paenibacillus. Cell-wall peptidoglycan of strain FeL05

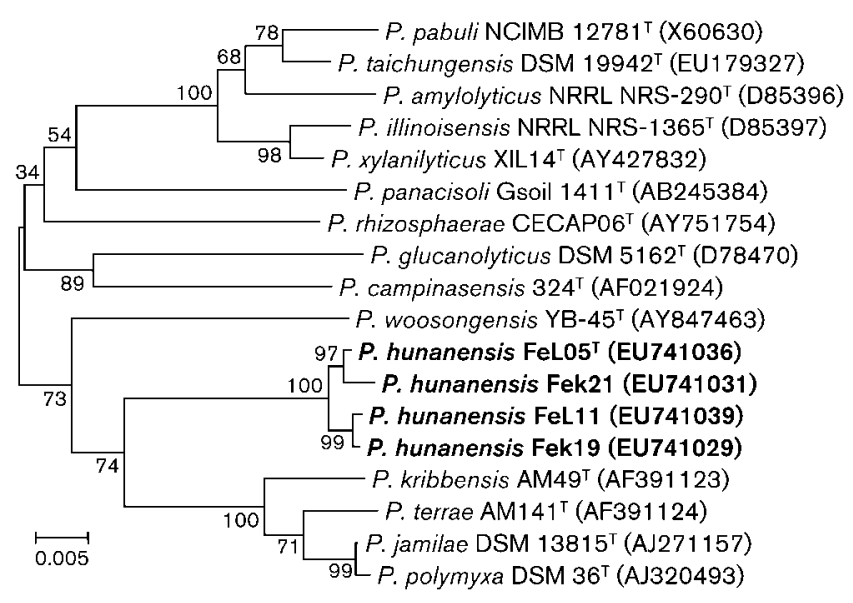

Fig. 1. Phylogenetic tree showing the relationships of the novel strains to closely related species within the genus Paenibacillus. The tree is based on an alignment of almost-complete 16S rRNA gene sequences and was constructed using the neighbour-joining method (Saitou \& Nei, 1987). The consensus phylogenetic tree was produced following bootstrap sampling of 1000 datasets. Numbers at nodes indicate percentages of bootstrap support based on a neighbour-joining analysis of 1000 resampled datasets. Bar, 0.005 substitutions per nucleotide position. 
Table 1. Characteristics that differentiate strains $\mathrm{FeL}^{\top}{ }^{\top}$, FeL11, Fek19 and Fek21 from type strains of closely related species of the genus Paenibacillus

Strains: 1, FeL05 ${ }^{\mathrm{T}}$ (strains FeL11, Fek19 and Fek21 gave identical results with the exception of the DNA G $+\mathrm{C}$ content; see text); $2, P$. kribbensis $\mathrm{AM}_{4} 9^{\mathrm{T}}$ (data from Yoon et al., 2003); 3, P. terrae $\mathrm{AM} 141^{\mathrm{T}}$ (Yoon et al., 2003); 4, P. rhizosphaerae CECAP06 ${ }^{\mathrm{T}}$ (Rivas et al., 2005); 5, P. woosongensis YB- $45^{\mathrm{T}}$ (Lee \& Yoon, 2008); 6, P. panacisoli Gsoil $1411^{\mathrm{T}}$ (Ten et al., 2006). +, Positive or present; $(+)$, weakly positive; - , negative or absent; $+/ \mathrm{v}$, Gram-variable; NR, not reported. All strains were positive for motility and catalase activity.

\begin{tabular}{|lcccccc|}
\hline Characteristic & $\mathbf{1}$ & $\mathbf{2}$ & $\mathbf{3}$ & $\mathbf{4}$ & $\mathbf{5}$ & $\mathbf{6}$ \\
\hline Capsules & + & $\mathrm{NR}$ & $\mathrm{NR}$ & $\mathrm{NR}$ & $\mathrm{NR}$ & $\mathrm{NR}$ \\
Gram stain & + & $+/ \mathrm{V}$ & $+/ \mathrm{v}$ & + & $+/ \mathrm{V}$ & + \\
Oxidase & - & - & - & + & - & + \\
Voges-Proskauer test & + & $\mathrm{NR}$ & $\mathrm{NR}$ & + & $\mathrm{NR}$ & - \\
Nitrate reduction & + & + & + & + & - & + \\
Hydrolysis of: & & & & & & \\
$\quad$ Casein & + & + & + & - & + & $(+)$ \\
$\quad$ Gelatin & - & + & + & - & - & + \\
$\quad$ Starch & + & + & + & $\mathrm{NR}$ & + & - \\
$\quad$ Aesculin & + & + & + & $\mathrm{NR}$ & + & - \\
$\quad$ Tween 80 & + & + & $(+)$ & $\mathrm{NR}$ & - & $\mathrm{NR}$ \\
Optimum temperature & 30 & $30-37$ & 30 & 28 & 37 & 37 \\
$\quad\left({ }^{\circ} \mathrm{C}\right)$ & & & & & & \\
Growth at/in: & & & & & & \\
$\quad 50{ }^{\circ} \mathrm{C}$ & - & - & - & + & - & - \\
pH 5.6 & + & + & + & $(+)$ & - & + \\
$5 \%(w / v) \mathrm{NaCl}$ & + & $\mathrm{NR}$ & $\mathrm{NR}$ & + & + & + \\
DNA G+C content & 53.3 & 48.0 & 47.0 & 51.3 & 51.7 & 53.9 \\
$\quad(\mathrm{~mol} \%)$ & & & & & & \\
\hline
\end{tabular}

contained meso-diaminopimelic acid, and it showed peptidoglycan type A1 $\gamma$ m-Dpm-direct (type A31, according to http://www.dsmz.de/microorganisms/main.php?content $\mathrm{id}=35$ ). The major polar lipids presented in strain FeL05 ${ }^{\mathrm{T}}$ were phosphatidylglycerol, diphosphatidylglycerol and phosphatidylethanolamine. Traces of phosphatidylserine and an unknown phospholipid were also detected. Cellular fatty acid profiles are shown in Supplementary Table S2. The major cellular fatty acids of strain FeL $05^{\mathrm{T}}$ were anteiso- $\mathrm{C}_{15: 0}$ $(61.7 \%), \mathrm{C}_{16: 0}(10.9 \%)$, iso- $\mathrm{C}_{16: 0}(7.0 \%)$, anteiso- $\mathrm{C}_{17: 0}$ $(6.7 \%)$ and iso- $\mathrm{C}_{15: 0}(5.2 \%)$. The fatty acid profiles of the four strains were similar to those of the type strains of the Paenibacillus species used in this study, but there were differences in the proportions of some fatty acids. Cells of strains FeL05 ${ }^{\mathrm{T}}$, FeL11, Fek19 and Fek21 stained Grampositive. Capsules were observed around cells of the four strains by light microscopy and electron microscopy. The menaquinone profile, with MK-7 as the major component, is in agreement with the description of the genus Paenibacillus. The DNA G $+\mathrm{C}$ contents of strains FeL05 ${ }^{\mathrm{T}}$, FeL11, Fek19 and Fek21 were respectively 53.3, 53.9, 52.0 and $54.9 \mathrm{~mol} \%$, which lie within the range of values reported for members of the genus Paenibacillus.
16S rRNA gene sequence similarity of less than $97 \%$ between bacterial strains indicates that they represent different species but, at $97 \% 16 \mathrm{~S}$ rRNA sequence similarity or above, DNA relatedness must be used to determine whether strains belong to different species (Stackebrandt \& Goebel, 1994). The bacterium with the greatest pairwise $16 \mathrm{~S}$ rRNA gene sequence similarity to strains $\mathrm{FeL} 05^{\mathrm{T}}$ was $P$. kribbensis $\mathrm{AM} 49^{\mathrm{T}}$ (95.35\% similarity), so DNA relatedness experiments with strains of known species were omitted.

In view of the combination of morphological, physiological, chemotaxonomic and phylogenetic data discussed here, it is evident that FeL05 ${ }^{\mathrm{T}}$, FeL11, Fek19 and Fek21 belong to the genus Paenibacillus. Differences in some phenotypic characteristics and their phylogenetic distinctiveness distinguish the four strains from previously described Paenibacillus species. On the basis of the data described above, the four strains represent a novel species of the genus Paenibacillus, for which the name Paenibacillus hunanensis sp. nov. is proposed.

\section{Description of Paenibacillus hunanensis sp. nov.}

Paenibacillus hunanensis (hu.nan.en'sis. N.L. masc. adj. hunanensis of Hunan, a province of China, from where the first strains were isolated).

Cells are Gram-stain-positive, aerobic or facultatively anaerobic, motile, endospore-forming, rod-shaped bacteria $(2.1-3.0 \times 0.7-1.0 \mu \mathrm{m})$. Capsules are observed by light microscopy and electron microscopy. Motile by means of peritrichous flagella (Supplementary Fig. S1). Ellipsoidal spores are formed in sporangia and in a subterminal position in cells. After 24-48 h growth on LB agar, colonies are up to 3-7 $\mathrm{mm}$ in diameter, circular and raised with entire edges and off-white to yellow. The optimum temperature for growth is $30{ }^{\circ} \mathrm{C}$ and the maximum growth temperature is $44{ }^{\circ} \mathrm{C}$. Optimum growth at $\mathrm{pH}$ 5.0-10.0. Reactions for catalase, nitrate reduction and hydrolysis of aesculin, Tween 80 , starch and casein are positive. Gelatin is not hydrolysed. Indole production and Voges-Proskauer tests are positive. Oxidase test is negative. Grows at $0-5 \%$ $\mathrm{NaCl}$. The culture medium becomes more alkaline during growth. Dextrin, glycogen, $N$-acetyl-D-glucosamine, amygdalin, L-arabinose, arbutin, cellobiose, D-fructose, Dgalactose, gentiobiose, D-gluconic acid, $\alpha$-D-glucose, $\alpha$ lactose, lactulose, maltose, maltotriose, D-mannitol, Dmannose, thymidine, melibiose, methyl $\alpha$-D-galactoside, pyruvic acid, methyl $\beta$-D-galactoside, 3-methyl D-glucose, methyl $\beta$-D-glucoside, palatinose, D-psicose, raffinose, Dribose, salicin, D-sorbitol, stachyose, sucrose, trehalose, Dxylose, glycerol, adenosine, inosine and uridine are used as sole carbon sources for energy and growth. In the API $50 \mathrm{CH}$ system, when API CHB suspension medium is used, acid is produced from L-arabinose, D-ribose, D-xylose, methyl $\beta$-D-xylopyranoside, D-galactose, D-glucose, $\mathrm{D}$ fructose, D-mannose, D-mannitol, $N$-acetylglucosamine, amygdalin, arbutin, aesculin, salicin, cellobiose, maltose, lactose, melibiose, sucrose, trehalose, raffinose, starch, 
glycogen and gentiobiose; acid is produced weakly from glycerol, inositol, methyl $\alpha$-D-glucopyranoside, inulin, turanose and gluconate. Acid is not produced from erythritol, D-arabinose, L-xylose, D-adonitol, L-sorbose, Lrhamnose, dulcitol, D-sorbitol, methyl $\alpha$-D-mannopyranoside, melezitose, xylitol, D-lyxose, D-tagatose, D- or Lfucose, D- or L-arabitol, 2-ketogluconate or 5-ketogluconate. Cell-wall peptidoglycan contains meso-diaminopimelic acid. The predominant menaquinone is MK-7. The major cellular fatty acids are anteiso- $C_{15: 0}, C_{16: 0}$, iso$\mathrm{C}_{16: 0}$, anteiso- $\mathrm{C}_{17: 0}$ and iso- $\mathrm{C}_{15: 0}$. The DNA $\mathrm{G}+\mathrm{C}$ content of the type strain is $53.3 \mathrm{~mol} \%$.

The type strain, FeL05 ${ }^{\mathrm{T}}$ (=ACCC $10718^{\mathrm{T}}=$ CGMCC $1.8907^{\mathrm{T}}=$ DSM $22170^{\mathrm{T}}$ ), was isolated from seeds of hybrid rice (Oryza sativa L.) sampled from Hunan Province, China. Strains FeL11, Fek19 and Fek21 are additional strains of the species, isolated from the same source.

\section{Acknowledgements}

We are very grateful to Professor Chunfang Song for offering hybrid rice seeds. This work was supported by the National Natural Science Foundation of China (nos 30370032 and 30770069), the Science Foundation of Beijing (no. 5092004), the Education Ministry Foundation of China (no. 20060028001), the Special Scientific Research Funds for commonweal agricultural industry (no. 200803029), the Special Foundation for Central Academy of Institute of Agricultural Resources and Regional Planning, Chinese Academy of Agricultural Sciences (no. 2009-10) and the Natural Science Foundation of Shanxi (no. 2008012010-3).

\section{References}

Beatty, P. H. \& Jensen, S. E. (2002). Paenibacillus polymyxa produces fusaricidin-type antifungal antibiotics active against Leptosphaeria maculans, the causative agent of blackleg disease of canola. Can J Microbiol 48, 159-169.

Chung, Y. R., Kim, C. H., Hwang, I. \& Chun, J. (2000). Paenibacillus koreensis sp. nov., a new species that produces an iturin-like antifungal compound. Int J Syst Evol Microbiol 50, 1495-1500.

Claus, D. \& Berkeley, R. C. W. (1986). Genus Bacillus Cohn 1872, $174^{\mathrm{AL}}$. In Bergey's Manual of Systematic Bacteriology, vol. 2, pp. 1105 1139. Edited by P. H. A. Sneath, N. S. Mair, M. E. Sharpe \& J. G. Holt. Baltimore: Williams \& Wilkins.

Collins, M. D. (1985). Isoprenoid quinone analysis in classification and identification. In Chemical Methods in Bacterial Systematics, pp. 267-287. Edited by M. Goodfellow \& D. E. Minnikin. London: Academic Press.

Collins, M. D. \& Jones, D. (1980). Lipids in the classification and identification of coryneform bacteria containing peptidoglycans based on 2,4-diaminobutyric acid. J Appl Bacteriol 48, 459470.

Eck, R. V. \& Dayhoff, M. O. (1966). Atlas of Protein Sequence and Structure. Silver Springs, MD: National Biomedical Research Foundation.

Felsenstein, J. (1985). Confidence limits on phylogenies: an approach using the bootstrap. Evolution 39, 783-791.

Fitch, W. M. (1971). Toward defining the course of evolution: minimum change for a specific tree topology. Syst Zool 20, 406-416.
Helbig, J. (2001). Biological control of Botrytis cinerea Pers. ex Fr. in strawberry by Paenibacillus polymyxa (isolate 18191). J Phytopathol 149, 265-273.

Hucker, G. J. \& Conn, H. J. (1923). Method of Gram staining. NY State Agric Exp Stn Tech Bull 93, 3-37.

Kämpfer, P. \& Kroppenstedt, R. M. (1996). Numerical analysis of fatty acid patterns of coryneform bacteria and related taxa. Can J Microbiol 42, 989-1005.

Lane, D. J. (1991). 16S/23S rRNA sequencing. In Nucleic Acid Techniques in Bacterial Systematics, pp. 115-175. Edited by E. Stackebrandt \& M. Goodfellow. Chichester: Wiley.

Lebuhn, M., Heulin, T. \& Hartmann, A. (1997). Production of auxin and other indolic and phenolic compounds by Paenibacillus polymyxa strains isolated from different proximity to plant roots. FEMS Microbiol Ecol 22, 325-334.

Lee, J.-C. \& Yoon, K.-H. (2008). Paenibacillus woosongensis sp. nov., a xylanolytic bacterium isolated from forest soil. Int $J$ Syst Evol Microbiol 58, 612-616.

MacKenzie, S. L. (1987). Gas chromatographic analysis of amino acids as the $N$-heptafluorobutyryl isobutyl esters. J Assoc Off Anal Chem 70, 151-160.

Maes, M. \& Baeyen, S. (2003). Experiences and perspectives for the use of a Paenibacillus strain as plant protectant. Commun Agric Appl Biol Sci 68, 457-462.

Marmur, J. (1961). A procedure for the isolation of deoxyribonucleic acid from microorganisms. J Mol Biol 3, 208-218.

Marmur, J. \& Doty, P. (1962). Determination of base composition of deoxyribonucleic acid from its denaturation temperature. $J$ Mol Biol 5, 109-118.

Minnikin, D. E., Collins, M. D. \& Goodfellow, M. (1979). Fatty acid and polar lipid composition in the classification of Cellulomonas, Oerskovia and related taxa. J Appl Bacteriol 47, 87-95.

Priest, F. G. (1977). Extracellular enzyme synthesis in the genus Bacillus. Bacteriol Rev 41, 711-753.

Qiu, F. B., Huang, Y., Sun, L., Zhang, X. X., Liu, Z. H. \& Song, W. (2007). Leifsonia ginsengi sp. nov., isolated from ginseng root. Int $J$ Syst Evol Microbiol 57, 405-408.

Rivas, R., Gutiérrez, C., Abril, A., Mateos, P. F., Martínez-Molina, E., Ventosa, A. \& Velázquez, E. (2005). Paenibacillus rhizosphaerae sp. nov., isolated from the rhizosphere of Cicer arietinum. Int J Syst Evol Microbiol 55, 1305-1309.

Rzhetsky, A. \& Nei, M. (1992). A simple method for estimating and testing minimum evolution trees. Mol Biol Evol 9, 945-967.

Saitou, N. \& Nei, M. (1987). The neighbor-joining method: a new method for reconstructing phylogenetic trees. Mol Biol Evol 4, 406425.

Sasser, M. (1990). Identification of bacteria by gas chromatography of cellular fatty acids, Technical note 101. Newark, DE: MIDI, Inc.

Schleifer, K. H. (1985). Analysis of the chemical composition and primary structure of murein. Methods Microbiol 18, 123-156.

Slepecky, R. \& Hemphill, E. (1992). The genus Bacillus - nonmedical. In The Prokaryotes, 2nd edn, pp. 1663-1696. Edited by A. Balows, H. G. Trüper, M. Dworkin, W. Harder \& K. H. Schleifer. New York: Springer.

Stackebrandt, E. \& Goebel, B. M. (1994). Taxonomic note: a place for DNA-DNA reassociation and $16 \mathrm{~S}$ rRNA sequence analysis in the present species definition in bacteriology. Int J Syst Bacteriol 44, 846849.

Tamura, K., Dudley, J., Nei, M. \& Kumar, S. (2007). MEGA4: molecular evolutionary genetics analysis (MEGA) software version 4.0. Mol Biol Evol 24, 1596-1599. 
Ten, L. N., Baek, S.-H., Im, W.-T., Lee, M., Oh, H. W. \& Lee, S.-T. (2006). Paenibacillus panacisoli sp. nov., a xylanolytic bacterium isolated from soil in a ginseng field in South Korea. Int J Syst Evol Microbiol 56, 2677-2681.

Thompson, J. D., Gibson, T. J., Plewniak, F., Jeanmougin, F. \& Higgins, D. G. (1997). The CLUSTAL_X windows interface: flexible strategies for multiple sequence alignment aided by quality analysis tools. Nucleic Acids Res 25, 4876-4882.

Timmusk, S. \& Wagner, E. G. (1999). The plant-growth-promoting rhizobacterium Paenibacillus polymyxa induces changes in Arabidopsis thaliana gene expression: a possible connection between biotic and abiotic stress responses. Mol Plant Microbe Interact 12, 951-959.

Timmusk, S., Nicander, B., Granhall, U. \& Tillberg, E. (1999). Cytokinin production by Paenibacillus polymyxa. Soil Biol Biochem 31, 1847-1852. von der Weid, I., Alviano, D. S., Santos, A. L., Soares, R. M., Alviano, C. S. \& Seldin, L. (2003). Antimicrobial activity of Paenibacillus peoriae strain NRRL BD-62 against a broad spectrum of phytopathogenic bacteria and fungi. J Appl Microbiol 95, 1143-1151.

Weon-Taek, S., Kahng, G. G., Nam, S. H., Choi, S. D., Suh, H. H., Kim, S. W. \& Park, Y. H. (1999). Isolation and characterization of a novel exopolysaccharide-producing Paenibacillus sp. WN9 KCTC 8951P. J Microbiol Biotechnol 9, 820-825.

Wu, C., Lu, X., Qin, M., Wang, Y. \& Ruan, J. (1989). The analysis of menaquinone compound in microbial cells by HPLC. Microbiology [English translation of Microbiology (Beijing)] 16, 176-178.

Yoon, J. H., Oh, H. M., Yoon, B. D., Kang, K. H. \& Park, Y. H. (2003). Paenibacillus kribbensis sp. nov. and Paenibacillus terrae sp. nov., bioflocculants for efficient harvesting of algal cells. Int J Syst Evol Microbiol 53, 295-301. 